\title{
STUDI PEMANFAATAN TUMBUHAN OBAT BERPOTENSI MENGOBATI PADA PENYAKIT PADA PENYAKIT SISTEM PENCERNAAN DI KELURAHAN BUNUT KECAMATAN KAPUAS KABUPATEN SANGGAU
}

(Study On The Use Of Medicinal Plants Have The Potential To Treat Diseases Of The Digestive System ByOf Bunut Village Of Kapuas Subdistrict Of Sanggau Regency)

\author{
Kurnia Ningsih, Yeni Mariani, Yanieta Arbiastutie, Fathul Yusro \\ Fakultas Kehutanan Universitas Tanjungpura Jalan Daya Nasional, Pontianak 78124 \\ E-mail : kurnianingsih404@gmail.com
}

\begin{abstract}
The study aims to document the medicinal plants and knowledge of the use of medicinal plants used by traditional healers in Bunut Village. This research was conducted in Bunut Village, Kapuas Subdistrict, Sanggau Regency, West Kalimantan. In this study, we found a total of 31 species of medicinal plants used by traditional healers and those included in the 25 plants family. The most common family is Zingiberaceae. Herbal habitus is the most common use (51,61\%). The plant part is leaves (53\%) used by traditional shamans from Bunut Village. The most widely used method of processing plants is boiling (64,87\%). The way of use that is often used is by drink (53\%). Usage rules that are commonly used are $2 x 1$ (65,63\%). Doses of using medicinal plants are 1-3 strands/part (45\%) and 4-6 strands/part (45\%).
\end{abstract}

Keywords: Bunut Village, Medicinal Plants, Sanggau Regency, Traditional Healer, Traditional Knowledge.

\section{PENDAHULUAN}

Kalimantan Barat merupakan salah satu provinsi di Indonesia yang terkenal dengan hutan tropika basahnya dan menyimpan berbagai jenis spesies tumbuhan yang dimanfaatkan oleh masyarakat secara tradisional, mulai dari berbagai habitus seperti tumbuhan lapisan bawah, liana, terna, perdu, dan berbagai jenis pohon lainnya. Hasil hutan baik berupa kayu maupun hasil hutan bukan kayu memiliki potensi yang tinggi untuk dimanfaatkan sebagai obat tradisonal seperti akar, kulit kayu, daun, bunga, getah, buah dan biji dan harus tetap dipertahankan sebagai bahan dalam pengobatan tradisional (Yusro 2011).

Tradisi pengobatan tradisional dapat ditelusuri kembali lebih lanjut dari berbagai daerah yang memanfaatkan tumbuhan sebagai obat tradisional. Pemanfaatan tumbuhan obat tersebut merupakan bagian pengetahuan tradisi masyarakat yang diwariskan dari zaman terdahulu secara turun-temurun hingga ke generasi sekarang dan melalui pengalaman pribadi yang ada, sehingga muncul berbagai ramuan herbal yang menjadi ciri khas dalam pengobatan tradisional. Upaya penyembuhan suatu penyakit dengan pengobatan tradisonal masih ada dikalangan masyarakat yang umumnya diolah secara tradisional dan ramuan obat-obatan yang berasal dari alam tersebut merupakan alternatif dan solusi untuk mengatasi masalah-masalah kesehatan yang dihadapi saat ini (Emilda $e t$ al. 2017). Pengetahuan masyarakat mengenai pemanfaatan tumbuhan obat 
harus terus dikembangkan agar tetap terjaganya informasi mengenai manfaat berbagai tanaman sebagai obat untuk menyembuhkan berbagai penyakit salah satunya adalah penyakit pada sistem pencernaan (Hamzari 2008).

Pemanfaatan tumbuhan sebagai obat terus berkembang dan meningkat dengan adanya penelitian terkait identifikasi dan pemanfaatan tumbuhan yang berpotensi sebagai obat dalam pengobatan tradisional. Rahman et al. (2019) menyatakan identifikasi jenis dan pemanfaatan tumbuhan obat di hutan tembawang oleh masyarakat Kelurahan Beringin Kecamatan Kapuas Kabupaten Sanggau di peroleh 100 spesies yang dimanfaatkan oleh masyarakat untuk berbagai macam penyakit salah satunya penyakit pada sistem pencernaan seperti jambu biji, mengkudu dan bandotan.Sari et al. (2015) menyatakan pemanfaatan tumbuhan obat pada masyarakat suku Dayak Jangkang Tanjung di Desa Ribau Kecamatan Kapuas Kabupaten Sanggau diperoleh 65 spesies tumbuhan obat untuk mengobati 25 penyakit umum dan 13 spesies tumbuhan seperti kelapa, galenggang dan cocor bebek untuk mengobati penyakit pada sistem pencernaan. Tangjitman et al. (2015) menyatakan 36 jenis tumbuhan obat seperti banglay hantu, kunyit dan kunyit hitam yang dimanfaatkan oleh masyarakat Karen di Thailand Utara, Darwis (2012) menyatakan 68 jenis tumbuhan obat seperti adas, belimbing manis dan bungur yang dimanfaatkan oleh masyarakat di Kota Bengkulu salah satunya adalah penyakit pada sistem pencernaan dan Yusro et al. (2019) memanfaatkan 21 jenis tumbuhan obat seperti buan, leban dan rumput cupek yang dapat mengobati gangguansistem pencernaan oleh suku Dayak Iban di Kabupaten Kapuas Hulu.

Sistem pencernaan pada manusia merupakan sistem pada organ vital tubuh yang berfungsi mengatur pencernaan setiap makanan dan minuman yang masuk ke dalam tubuh manusia dari ukuran yang besar hingga menjadi ukuran yang halus. Organ-organ vital pada tubuh terkait sistem pencernaan tersebut harus tetap dijaga karena penyakit pada saluran pencernaan merupakan penyakit yang berbahaya dan memiliki resiko kematian dikalangan masyarakat. WHO (World Health Organization) menyatakan penyakit pada saluran pencernaan, yang paling banyak menyebabkan kematian nomor 6 di dunia adalah salah satunya penyakit kanker usus dan penyakit yang menyebabkan kematian nomor 7 di dunia adalah penyakit diare.(Istiqomah dan Abdul 2013).

Fasilitas pelayanan kesehatan Kabupaten Sanggau sudah mulai berkembang yang ditandai dengan adanya puskesmas, rumah sakit dan fasilitas kesehatan modern lainnya. Fasilitas kesehatan tersebut memberi dampak terhadap penggunaan dan pemanfaatan tumbuhan obat serta pengobatan dengan cara tradisional atau alami yang mulai kurang diminati masyarakat setempat, walaupun demikian masyarakat Kelurahan Bunut Kecamatan Kapuas Kabupaten Sanggau yang sebagian besar penduduknya beretnis melayu dan dayak masih menggunakan tumbuhan untuk mengobati berbagai penyakit yang diderita, salah satunya penyakit pada sistem pencernaan. 
Masyarakat Kelurahan Bunut Kecamatan Kapuas Kabupaten Sanggau menilai pengobatan dengan cara tradisional lebih murah dan mudah dijangkau oleh semua kalangan, selain itu khasiat dari tumbuhan obat lebih aman dan minim efek samping apabila digunakan sesuai dengan dosis yang telah ditentukan (Sada dan Tanjung 2010), maka dari itu diperlukannya penelitian mengenai pemanfaatan tumbuhan obat berpotensi mengobati penyakit pada sistem pencernaan di Kelurahan Bunut Kecamatan Kapuas Kabupaten Sanggau.

Tujuan penelitian ini yaitu untuk mendokumentasikan

pengetahuantumbuhan obat yang digunakan oleh dukun tradisional (pengobatan tradisional) berpotensi mengobati penyakit pada sistem pencernaan di Kelurahan Bunut Kecamatan Kapuas Kabupaten Sanggau. Manfaat penelitian ini yaitu memperoleh dokumentasi tumbuhan yang digunakan oleh dukun tradisional (pengobatan tradisional) yang berpotensi mengobati penyakit pada sistem pencernaan di Kelurahan Bunut Kecamatan Kapuas Kabupaten Sanggau agar tetap bisa di budidaya dan dipertahankan keberadaannya oleh masyarakat sekitar dan semua pihak dalam rangka mengkonservasi tumbuhan obat.

\section{METODE PENELITIAN}

Penelitian ini dilakukan di Kelurahan Bunut Kecamatan Kapuas Kabupaten Sanggau selama 4 minggu mulai dari tanggal 1 Juni 2019 sampai dengan tanggal 1 Juli 2019 dan dilanjutkan dengan pengolahan data. Alat yang digunakan antara lain kuisioner atau daftar pertanyaan untuk responden, kamera dan perekam suara. Objek penelitian yang dijadikan sebagai responden adalah dukun tradisional dengan beberapa kriteria yaitu dukun tradisional tersebut berada atau tinggal di Kelurahan Bunut Kecamatan Kapuas Kabupaten Sanggau, mengetahui pemanfaatan tumbuhan obat yang digunakan sebagai obat tradisional (pengobatan tradisional), sehat jasmani dan rohani, serta memiliki pasien. Pemilihan responden dukun tradisional ini dilakukan dengan menggunakan metode snowball sampling.

Hasil wawancara mengenai jenis tumbuhan yang diperoleh selanjutnya dilakukan identifikasi jenis tumbuhan dengan literatur buku identifikasi mengenai nama lokal dan latin, famili, habitus, bagian yang digunakan, cara pengolahan, cara penggunaan, dan manfaatnya. Analisis kuantitatif akan memberikan gambaran dan penjelasan terkait persentase pemanfaatan tumbuhan obat mengenai famili tumbuhan, habitus tumbuhan, bagian tumbuhan yang digunakan, cara pengolahan tumbuhan, cara penggunaan tumbuhan, aturan penggunaan, dan dosis penggunaan.

\section{HASIL DAN PEMBAHASAN}

Hasil wawancara dengan 4 orang dukun tradisional dan terdata terdapat 31 jenis tumbuhan obat yang berpotensi mengobati penyakit pada sistem pencernaan yaitu maag, diare, sariawan, sakit gigi, wasir, sembelit dan radang tenggorokan.

\section{Famili Tumbuhan Obat}

Hasil penelitian ini diperoleh 25 jenis famili tumbuhan obat yang dimanfaatkan 
oleh dukun tradisional untuk mengobati penyakit pada sistem pencernaan. FamiliZingiberaceae merupakan famili yang paling banyak dimanfaatkan oleh dukun tradisional yaitu sebanyak 3 spesies, sedangkan familiAsteraceae, Amaryllidaceae, Apocynaceae, dan
Piperaceae masing-masing sebanyak 2 spesies, dan untuk famili yang lainnya sebanyak 1 spesies. Untuk hasil yang lebih jelas akan disajikan tumbuhan obat berdasarkan famili, persentase dapat dilihat pada Gambar 1.

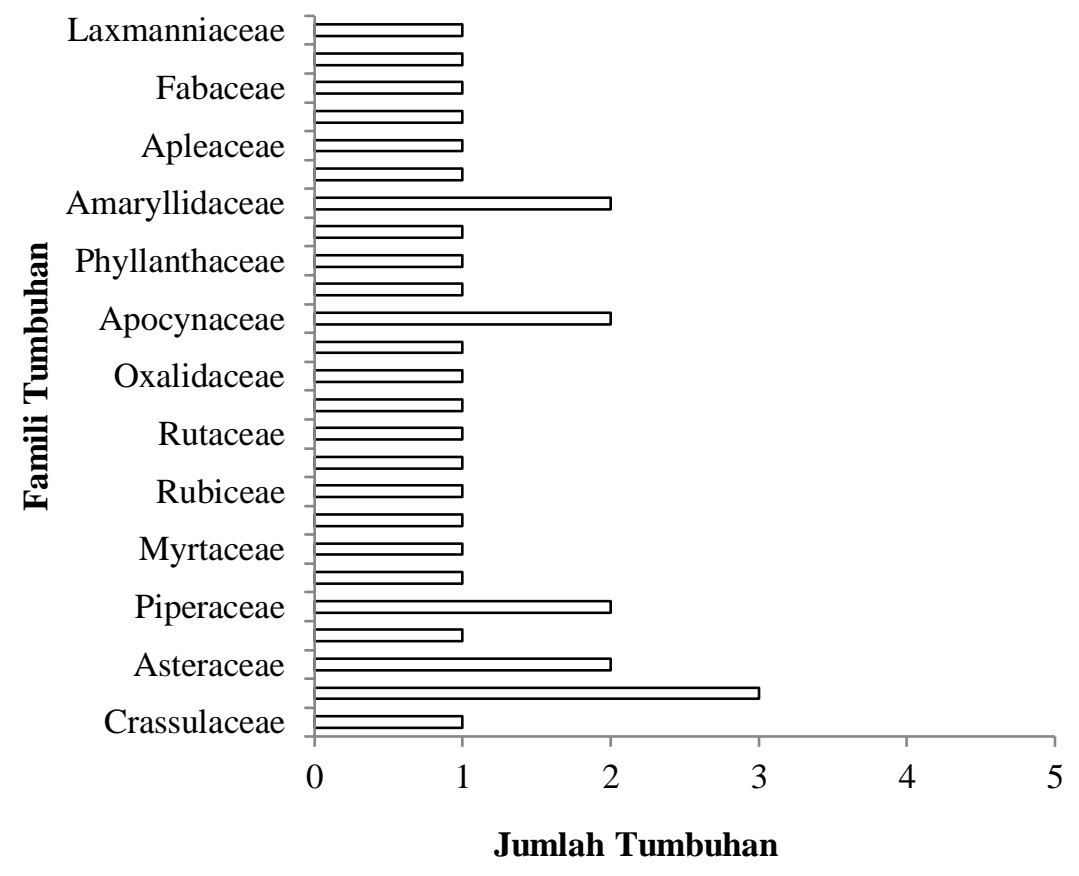

\section{Gambar 1. Famili Tumbuhan Obat (Family of Medicinal Plants)}

Tumbuhan obat yang dimanfaatkan oleh dukun tradisional lebih banyak ditemui berasal dari familiZingiberaceae. Kandungan kimia dari famili Zingiberaceae umumnya yaitu minyak atsiri, pati, tanin, dan damar dimana kandungan dari minyak atsiri yang dapat menstabilkan sistem syaraf, menimbulkan perasan senang dan tenang serta dapat menyembuhkan penyakit (Hartanto et al. 2014).

Minyak atsiri bermanfaat sebagai bahan obat-obatan karena kandungan senyawanya berfungsi melancarkan peredaran darah, sebagai penenang, antiseptik, antipiretik yaitu berupa penurun panas, karminatif dan memperbaiki gangguan sistem pencernaan. Hal ini terdapat senyawa metabolit sekunder pada sistem pencernaan yang pada umumnya dapat menghambat pertumbuhan mikroorganisme patogen yang merugikan bagi kesehatan tubuh (Hartanto et al. 2014)

Penelitian ini sejalan dengan Basenda et al. (2018) pada etnis banjar di Kecamatan Banjarmasin Timur Kota Banjarmasin, Yasir dan Anas (2018) di Desa Batu Hamparan Kabupaten Aceh Tenggara yang mengungkapkan bahwa famili Zingiberaceae bermanfaat 
menyembuhkan penyakit pada sistem pencernaan seperti batuk, maag, diare dan sariawan, serta Yusro et al. (2019) di Kapuas Hulu menemukan 4 spesies tumbuhan berfamili Zingiberaceae bermanfaat menyembuhkan gangguan pada sistem pencernaan.

\section{Habitus Tumbuhan Obat}

Tumbuhan obat yang dimanfaatkan oleh dukun tradisional berdasarkan habitus terdiri dari pohon, herba, liana, perdu dan semak. Habitus yang paling banyak dimanfaatkan yaitu herba $(51,61 \%)$ danperdu $(25,81)$ serta habitus lainnya yang banyak dimanfaatkan adalah semak $(12,90 \%)$, pohon $(6,45 \%)$, dan sedangkan liana $(3,23 \%)$. Persentase tumbuhan obat berdasarkan habitus ditampilkan pada Gambar 2.

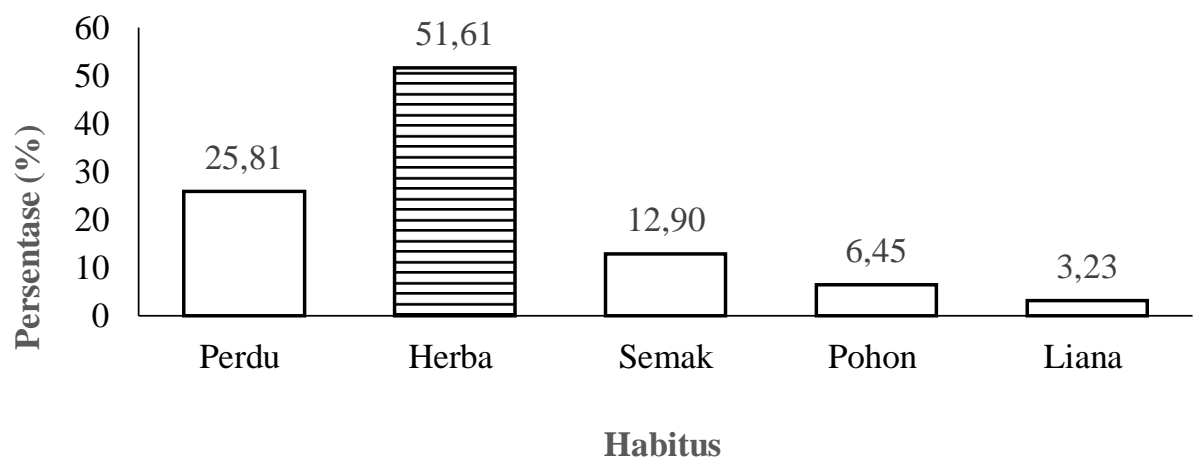

Gambar 2. Persentase Habitus (Percentage of Habitus)

Penelitian ini menunjukan bahwa habitus yang paling banyak ditemui dari spesies tumbuhan yaitu tingkat herba sebesar 51,61\% dikarenakan pada herba yang mudah untuk dibudidayakan dan tidak memerlukan lahan yang luas. Penelitian ini sejalan dengan Nurhaida $e t$ al.(2015) menyatakan bahwa pada habitus herba merupakan tumbuhan semusim yang sangat mudah penamaannya, cepat dalam pertumbuhan, tidak memerlukan lahan luas dan cukup diperkarangan rumah. Penelitian Mingga et al. (2019) di Desa Raba Kecamatan Menjalin Kabupaten Landak memperoleh sebanyak 13 spesies berhabitus herba.

\section{Bagian yang Digunakan}

Bagian tumbuhan yang digunakan oleh dukun tradisional sebagai obat berupa daun, barang, buah, bunga, getah, rimpang dan akar. Bagian tumbuhan yang paling banyak digunakan adalah daun $(53 \%)$, bagian tumbuhan lainnya yang banyak digunakan adalah buah (17\%), bagian tumbuhan lainnya yang cukup banyak digunakan adalah rimpang (9\%), umbi (9\%) dan batang (6\%), sedangkan bagian tumbuhan yang paling sedikit digunakan adalah getah (3\%) dan akar (3\%). Persentase bagian tumbuhan yang digunakan disajikan pada Gambar 3. 


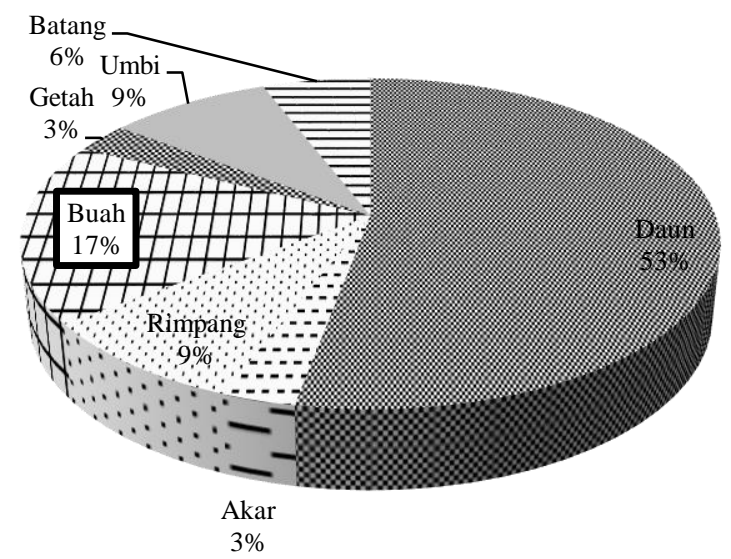

\section{Gambar 3. Persentase Bagian yang digunakan (Percentage of Parts Used)}

Pada penelitian ini daun (53\%) merupakan bagian yang paling banyak digunakan oleh dukun tradisional di Kelurahan Bunut Kecamatan Kapuas Kabupaten Sanggau untuk mengobati penyakit pada sistem pencernaan. Tingginya penggunaan daun oleh dukun tradisional dalam mengobati penyakit karena menurut informasi yang diperoleh bahwa bagian daun yang digunakan merupakan warisan pengetahuan dari nenek moyang terdahulu, daun mudah didapat dan proses preparasinya cukup sederhana serta tidak merusak bagian lain dari tumbuhan.

Dukun tradisional juga mengatakan bahwa pemanfaatan pada daun tidak menimbulkan suatu pengaruh besar terhadap suatu pertumbuhan suatu spesies dibandingkan dengan bagian batang atau akar dari tumbuhan tersebut dan tidak berdampak buruk bagi kelangsungan hidup tumbuhan sendiri. Karmila santi dan Supartini (2011) juga sepakat dan menyatakan bahwa daun merupakan bagian yang paling banyak dimanfaatkan sebagai obat sebanyak 20 spesies dan 1 spesies yaitu Medinilla alternifolia untuk mengobati diare. Yusro et al. (2019) menyatakan bahwa sebanyak 7 spesies tumbuhan yang memanfaatkan bagian daun untuk mengobati gangguan sistem pencernaan oleh suku Dayak Iban di Kabupaten Kapuas Hulu.

\section{Cara Pengolahan}

Bagian tumbuhan obat yang digunakan oleh dukun berdasarkan cara pengolahan yaitu tidak diolah, tumbuk, rebus dan parut. Berdasarkan cara-cara tersebut cara pengolahan yang paling banyak digunakan adalah rebus $(64,87 \%)$, dan tidak diolah $(18,92 \%)$, sedangkan cara pengolahan tumbuhan obat yang paling sedikit digunakan adalah ditumbuk $(10,81 \%)$ dan diparut $(5,41 \%)$. Persentase cara pengolahan disajikan pada Gambar 4. 


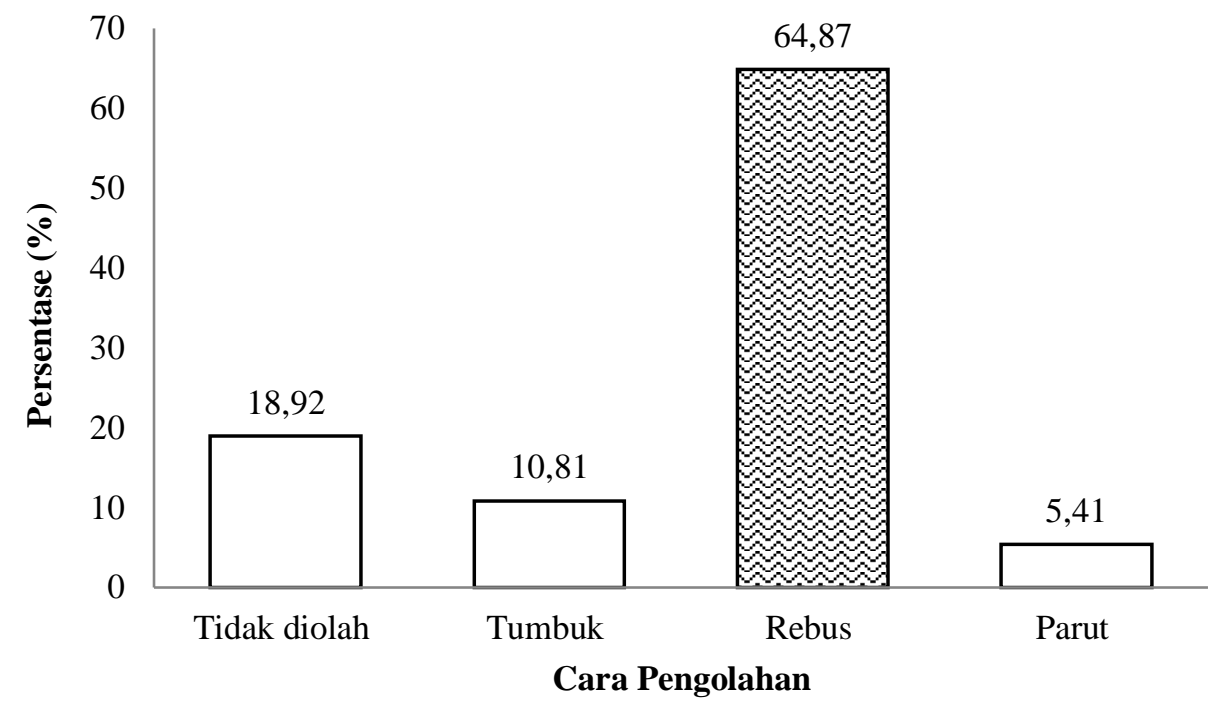

\section{Gambar 4. Persentase Tumbuhan Obat Berdasarkan Cara Pengolahan (Percentage Medicinal Plants Based On Processing Method)}

Penelitian ini menemukan bahwa pengolahan dengan cara direbus $(64,87 \%)$ lebih banyak digunakan oleh dukun, hal ini dikarenakan pengolahan dengan cara direbus akan mengeluarkan lebih banyak kandungan zat-zat didalamnya dan dengan direbus pada temperatur cukup tinggi maka kelarutan suatu zat semakin besar, serta cara ini pula umum dan sudah biasa digunakan secara turun menurun oleh nenek moyang terdahulu. Jalius dan Muswita (2013) berpendapat bahwa melalui teknik perebusan akan mengeluarkan kandungan senyawa aktif yang terdapat pada bagian tumbuhan terutama pada bagian tumbuhan yang memiliki hasil metabolit sekunder yang banyak yaitu daun yang sangat mudah larut dalam air sehingga mudah untuk dicerna oleh tubuh.

Hasil penelitian ini sejalan dengan penelitian Lestaridewiet al. (2017) menemukan sebanyak 20 jenis tumbuhan yang diolah dengan cara direbus yang digunakan oleh masyarakat di Desa Tolai Kecamatan Torue Kabupaten Parigi Moutong dan terdapat 7 jenis diantaranya seperti sirsak, pepaya, temulawak, serai, sambung nyawa, sirih, dan jambu biji dimanfaatkan untuk mengobati penyakit pada sistem pencernaan seperti batuk, sakit gigi, diare dan maag.

\section{Cara Penggunaan}

Berdasarkan cara penggunaannya pemanfaatan tumbuhan obat yaitu tempel, gosok, makan, minum dan kumur. Dari kelima cara penggunaan tersebut yang paling banyak digunakan adalah minum (53\%), dan makan (17\%). Cara penggunaan yang cukup banyak digunakan adalah tempel (15\%), sedangkan cara penggunaan yang paling sedikit digunakan adalah kumur (13\%) dan gosok (2\%). Persentase cara penggunaan disajikan pada Gambar 5. 


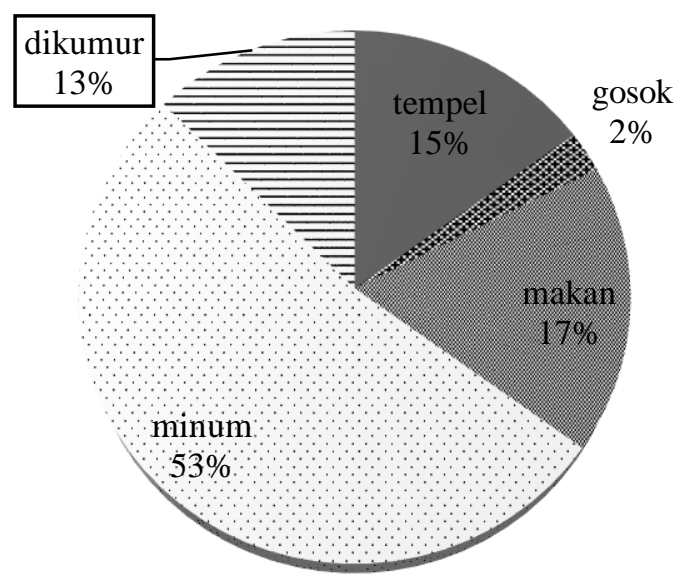

\section{Gambar 5. Persentase Tumbuhan Obat Berdasarkan Cara Penggunaan (Percentage of Medicinal Herbs Based on How to Use)}

Penelitian di Kelurahan Bunut Kecamatan Kapuas Kabupaten Sanggau memberikan hasil bahwa cara penggunaan dengan cara diminum (53\%) menunjukan hasil yang lebih banyak. Tumbuhan yang digunakan dengan cara diminum seperti pandan wangi untuk menyembuhkan penyakit wasir, mengkudu untuk menyembuhkan penyakit maag dan wasir, jahe untuk menyembuhkan penyakit radang tenggorokan dan sembelit, bangle untuk menyembuhkan penyakit diare dan maag.

Tingginya penggunaan dengan cara diminum oleh dukun dalam mengobati penyakit terkait pencernaan, diduga bahwa dukun tradisional meyakinkan dengan cara diminum penyakit yang mereka rasakan akan lebih cepat pulih dan memberikan reaksi yang langsung terhadap kesembuhan penyakit yang dideritanya (I'ismi et al., 2018). Hal ini sejalan dengan penelitian Gunadi et al. (2017) yang mendapatkan penggunaan dengan cara diminum pada masyarakat etnisdayak di Desa Gerantung
Kecamatan Monterado Kabupaten Bengkayang sebanyak 23 spesies (44\%) dan 5 spesies diantaranya dapat mengobati penyakit terkait pencernaan seperti sariawan, radang tenggorokan, diare dan maag.

Pemanfaatan tumbuhan obat oleh dukun tradisional ada tambahan bahan seperti garam, gula pasir, gula merah, kecap manis dan kapuk. Penambahan garam untuk tumbuhan jambu biji, pandan wangi, serai, patang tulang dan meniran serta cabe rawit. Penambahan gula untuk tumbuhan kunyit, nangka belanda, sirih, pinang, pandan wangi, dan temulawak. Penambahan gula merah untuk tumbuhan jahe. Penambahan kapuk pada tumbuhan bangle. Penambahan gula pasir, garam, gula merah, kecap manis, dan kapuk menurut dukun tradisional merupakan pengetahuan turun menurun yang sudah sejak dahulu dimanfaatkan oleh nenek moyang setempat.

\section{Aturan Penggunaan}

Berdasarkan aturan penggunaan atau berapa kali dalam sehari masyarakat 
di Desa menggunakan tumbuhan obat terdapat empat jenis penggunaan yaitu 1 $\mathrm{x} 1$ hari, $2 \times 1$ hari dan $3 \times 1$ hari. Penggunaan yang paling banyak adalah $2 \times 1$ hari $(65,63 \%)$, yang cukup banyak adalah 3 x 1 hari $(31,25 \%)$ dan penggunaan paling sedikit adalah $1 \times 1$ hari $(3,13 \%)$. Persentase penggunaan disajikan pada Gambar 6.

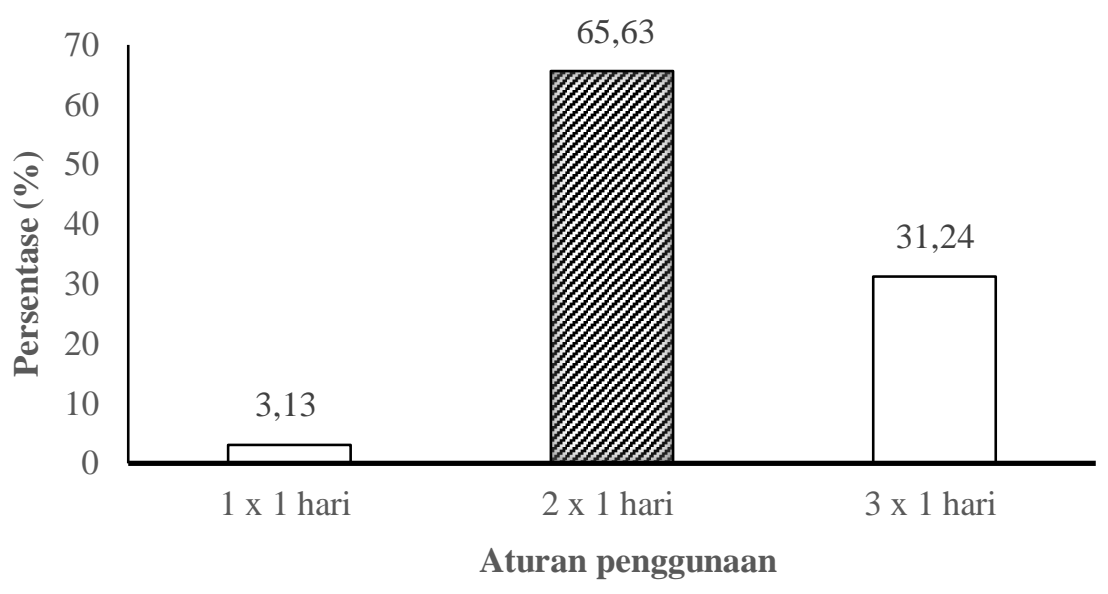

Gambar 6. Persentase Aturan Penggunaan (Percentage of Rules of Use)

Aturan penggunaan ini diperkenalkan dan diterapkan oleh dukun tradisonal karena aturan ini yang umumnya digunakan yaitu $2 \times 1$ sebesar $65,63 \%$ dan $3 \times 1$ hari sebesar $31,24 \%$. Tumbuhan dengan aturan penggunaan $2 \times 1$ digunakan oleh tumbuh daun seperti kemangi untuk menyembuhkan penyakit diare dan radang tenggorokan, pelaik untuk menyembuhkan sakit gigi, meniran untuk menyembuhkan sakit gigi, seledri untuk menyembuhkan sakit radang tenggorokan, bandotan dan suruhan untuk menyembuhakan penyakit diare serta andong untuk menyembuhkan penyakit diare dan wasir. Aturan penggunaan 2 x 1 umumnya yaitu pada waktu pagi dan sore hari karena memberikan efek yang baik bagi pemulihan kesehatan dan reaksi dari tumbuhan obat yang dikonsumsi sebagai penyembuhan sangat baik.
Hasil penelitian ini sejalan dengan penelitian Lestaridewi et al. (2017) di Desa Tolai Kecamatan Torue Kabupaten Perigi Moutong yang memanfaatkan 11 spesies tumbuhan untuk menyembuhkan penyakit pada sistem pencernaan seperti daun gedi, lidah buaya, jeruk nipis, temulawak, kunyit putih, serai, jarak pagar, ubi kayu, teratai, jambu biji dan jahe merah

\section{Dosis Penggunaan}

Berdasarkan pada penelitian di Kelurahan Bunut di peroleh dosis penggunaan pada setiap bagian yang digunakan untuk pengobatan yaitu 1-3 helai/bagian, 4-6 helai/bagian, dan > 7 helai/bagian. Dosis penggunaan yang paling banyak digunakan adalah 4-6 helai/bagian (45\%), yang cukup banyak digunakan adalah 1-3 helai/bagian (45\%), dan yang paling sedikit digunakan adalah $>7$ helai/bagian (10\%). Persentase dosis penggunaan disajikan pada Gambar 7. 


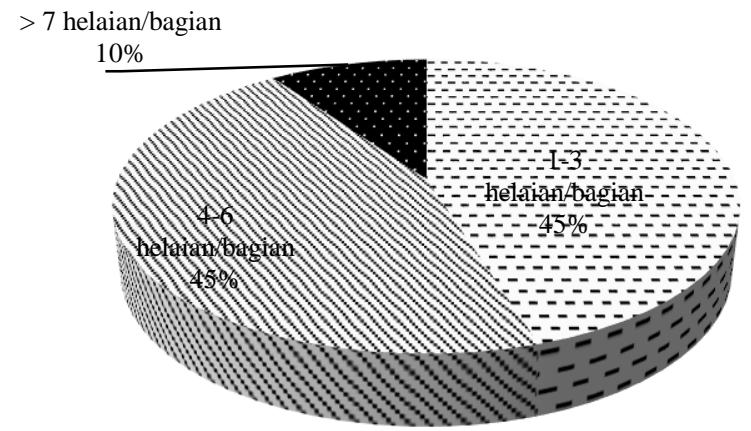

\section{Gambar 7. Persentase Tumbuhan Obat Berdasarkan Dosis Penggunaan (Percentage of Medicinal Herbs Based on The Dose of Use)}

$\begin{array}{lcrr}\text { Dosis penggunaan yang } & \text { paling } \\ \text { sering digunakan } & \text { adalah } & 4-6 \\ \text { helaian/bagian } \quad(45 \%) & \text { dan } & 1-3 \\ \text { helaian/bagian } & (45 \%), & \text { dimana }\end{array}$
penggunaan dosis yang sesuai akan mempercepat reaksi obat dan tidak menimbulkan efek samping yang sangat berarti. Tumbuhan yang memiliki dosis penggunaan 4-6 helaian/bagian seperti 6 helai daun meniran untuk menyembuhka sakit gigi, 5 helai daun wungu dan lidah mertua untuk menyembuhkan penyakit wasir, 5 helai daun bandotan dan suruhan untuk menyembuhkan penyakit diare, dan 5 helai daun tapak dara untuk menyembuhakan penyakit wasir dan radang tenggorokan. Dimana konsumsi obat sesuai dengan kadar dosis penggunaan umumya bersifat individual atau tergantung persepsi kondisi kesehatan pribadi, disarankan mengkonsumsi obat dengan dosis rendah terdahulu per hari kemudian adanya penambahan dosis penggunaan pada selang waktu 2-3 minggu sesuai kondisi tubuh karena setiap tubuh yang sakit memerlukan dosis yang optimum yaitu dosis yang seimbang dimana dosis tersebut tidak terlalu rendah dan tidak terlalu tinggi (Riwu et al. 2015).

\section{KESIMPULAN DAN SARAN}

Terdapat 31 spesies tumbuhan yang dimanfaatkan oleh dukun tradisional untuk mengobati penyakit pada sistem pencernaan yaitu untuk penyakit maag, diare, sakit gigi, sariawan, wasir, radang tenggorokan, dan sembelit.Famili tumbuhan obat yang terbanyak digunakan adalah famili Zingiberaceae sebanyak 3 spesies tumbuhan.Habitus tumbuhan obat yang terbanyak dimanfaatkan adalah herba $(51,61 \%)$. Bagian tumbuhan yang terbanyak digunakan adalah daun (53\%). Cara pengolahan tumbuhan obat yang terbanyak digunakan adalah direbus $(64,87 \%)$. Cara penggunaan tumbuhan obat yang terbanyak digunakan adalah diminum (53\%). Aturan penggunaan tumbuhan obat yang terbanyak digunakan adalah $2 \times 1$ hari $(65,63 \%)$. Dosis penggunaan tumbuhan obat digunakan adalah 1-3 helai/bagian (45\%). Dari penelitian ini maka perlu dilakukan penelitian lebih lanjut untuk mengetahui komponen bioaktif dan 
bioaktivitasnya sebagai bahan baku obat-obatan untuk mengobati penyakit pada system pencernaan seperti andong, wungu, sengkodok, putri malu, suruhan dan meniran

\section{DAFTAR PUSTAKA}

Basenda MI, Noor C, Valentina MS,. 2018. Tinjauan Etnofarmakologi Tumbuhan Obat Pada Etnis Banjar di Kecamatan Banjarmasin Timur Kota Banjarmasin. Indonesia Natural Research Pharmaceitical Journal 2(2):1-12

Darwis W. 2012. Tanaman Obat Yang Terdapat Dikota Bengkulu Yang Berpotensi Sebagai Obat Penyakit Dan Gangguan Pada Sistem Pencernaan Manusia. Konservasi Hayati 8(1):1-15

Emilda, Muslihatul H, Heriyati. 2017. Analisis Pengetahuan Masyarakat Tentang Pemanfaatan Tanaan Obat Keluarga (Studi Kasus Kelurahan Situgede Kecamatan Bogor Barat). Sainmatika 14(1):11-21

Gunadi D, H.A.O, Gusti ET. 2015. Studi Tumbuhan Obat Pada Etnis Dayak di Desa Gerantung Kecamatan Monterado Kabupaten Bengkayang. Jurnal Hutan Lestari 5(2):425-436

Hamzari. 2008. Identifikasi Tanaman Obat-Obatan Yang Di Manfaatkan Oleh Masyarakat Sekitar Hutan Tabo-Tabo. Jurnal Hutan dan Masyarakat 3(2):111-234

Hartanto S, Fitmawati, Neri S. 2014. Studi Etnobotani Famili Zingiberaceae Dalam Kehidupan Masyarakat Lokal di Kecamatan Pangean Kabupaten Kuantan
Singingi, Riau. Biosaintifika 6(2):122-132

I'ismi B, Ratna H, Muflihati. 2018. Pemanfaatan Tumbuhan Obat Oleh Masyarakat di Sekitar Areal IUPHHK-HTI PT. BHATARA ALAM LESTARI di Kabupaten Mempawah. Jurnal Hutan Lestari 6(1):16-24

Istiqomah YN, Adul F.2013. Sistem Pakar Untuk Mengidentifikasi Penyakit Pencernaan Menggunakan Metode Deempster Shafer. Jurnal Sarana Teknik Informatika 1(1):32-41

Jalius, Muswita. 2013. Eksplorasi Pengetahuan Lokasi tentang Tumbuhan Obat di Suku Batin Jambi. Biospeciese 6(1):28-37

Karmilasanti, Supartini. 2011. Keanekaragaman Jenis Tumbuhan Obat dan Pemanfaatannya di Kawasan Tane' Olen Desa Setulang Malinau Kalimantan Timur. Jurnal Penelitian Dipterokarpa 5(1):23-28

Lestaridewi NK, Mohammad J, Isnainar. 2017. Kajian Pemanfaatan Tanaman Sebagai Obat Tradisional di Desa Tolai Kecamatan Torue Kabupaten Parigi Moutong. E-JIP BIOL 5(2):92-108

Mingga M, H A Oramahi, Gusti ET. 2019. Pemanfaatan Tumbuhan Obat Oleh Masyarakat di Desa Raba Kecamatan Menjalin Kabupaten Landak. Jurnal Hutan Lestari 7(1):97-105

Nurhaida, Fadillah HU, Gusti ET. 2015. Studi Etnobotani Tumbuhan Obat di Dusun Kelampuk Kecamatan Tanah Pinoh Barat Kabupaten 
Melawi. Jurnal Hutan Lestari 3(4):526-537

Rahman K, Evy W, Yeni M. 2019. Identifikasi Jenis dan Pemanfaatan Tumbuhan Obat di Hutan Tembawang oleh Masyarakat Kelurahan Beringin Kecamatan Kapuas Kabupaten Sanggau. Jurnal Hutan Lestari 7(1):44-55

Riwu M, Anas S, Keri L. 2015. Korelasi Faktor Usia, Cara Minum, dan Dosis Obat Metformin Terhadap Resiko Efek Samping Pada Penderita Diabates Melitus Tipe 2. Jurnal Farmasi Klinik Indonesia 4(3):151-161

Sada J, Rosye HRT. 2010. Keragaman Tumbuhan Obat Tradisional di Kampung Nansfori Distrik Supiori Utara Kabupaten Supior Papua. Jurnal Biologi Papua 2(2):39-46

Sari A, Riza L, Irwan L. 2015. Pemanfaatan Tumbuhan Obat pada Masyarakat Suku Dayak Jangkang Tanjung di Desa Ribau Kecamatan Kapuas Kabupaten Sanggau. Protobiont 4(2):1-8
Tangjitman K, Chalobol W, Kaweesin K, Treetip S, Chusie T. 2015. Ethnomedicinal Plants Used For Digestive System Disorders By The Karen of Northern Thailand. Journal of Ethnobiology and Ethnomedicine 11(27):1-13

Yassir M, Asnah. 2018. Pemanfaatan Jenis Tumbuhan Obat Tradisional di Desa Batu Hamparan Kabupaten Aceh Tenggara. Jurnal Biotik 6(1):17-34

Yusro F. 2011. Rendaman Ekstrak Etanol Dan Uji Fitokimia Tiga Jenis Tumbuhan Obat Kalimantan Barat. Jurnal Tengkawang 1(1):29-31

Yusro F, Yeni M, Evy W. 2019. Pemanfaatan Tumbuhan Obat Untuk Mengatasi Gangguan Sistem Pencernaan Oleh Suku Dayak Iban: Studi Kasus di Kabupaten Kapuas Hulu, Kalimantan Barat. Jurnal Borneo Akcaya 5(1):58-72 